\title{
Small Unconventional Hydrocarbon Gas Reservoirs as Challenging Energy Sources, Case Study from Northern Croatia
}

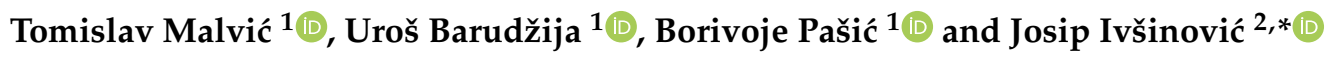 \\ 1 Faculty of Mining, Geology and Petroleum Engineering, University of Zagreb, HR-10000 Zagreb, Croatia; \\ tomislav.malvic@rgn.unizg.hr (T.M.); uros.barudzija@rgn.unizg.hr (U.B.); borivoje.pasic@rgn.unizg.hr (B.P.) \\ 2 Field Development, INA-Industry of Oil Plc., Av. V. Holjevca 10, HR-10000 Zagreb, Croatia \\ * Correspondence: josip.ivsinovic@ina.hr
}

Citation: Malvić, T.; Barudžija, U.;

Pašić, B.; Ivšinović, J. Small

Unconventional Hydrocarbon Gas Reservoirs as Challenging Energy Sources, Case Study from Northern Croatia. Energies 2021, 14, 3503.

https://doi.org/10.3390/en14123503

Academic Editor: Felix Barreras

Received: 4 April 2021

Accepted: 10 June 2021

Published: 12 June 2021

Publisher's Note: MDPI stays neutral with regard to jurisdictional claims in published maps and institutional affiliations.

Copyright: (c) 2021 by the authors. Licensee MDPI, Basel, Switzerland. This article is an open access article distributed under the terms and conditions of the Creative Commons Attribution (CC BY) license (https:// creativecommons.org/licenses/by/ $4.0 /)$.
Abstract: Small possible hydrocarbon gas reservoirs were analysed in the Bjelovar Subdepression in Northern Croatia. This area includes the Neogene-Quaternary, mostly clastics, sequences, reaching $3000+$ metres in the deepest part. The shallow south-eastern part of the Drava Depression contains a subdepression characterised with several, mostly small, discovered hydrocarbon fields, where the majority are located on the northern subdepression margin. The reason is the large distance from the main depressional migration pathways and main, deep, mature source rock depocenters. However, two promising unconventional targets were discovered inside the subdepression and both were proven by drilling. The first are source rocks of Badenian, of kerogen type III in early catagenesis, where partially inefficient expulsion probably kept significant gas volumes trapped in the source rock during primary migration. Such structures are the Western Bjelovar (or Rovišće) and the Eastern Bjelovar (or Velika Ciglena) Synclines. The second promising unconventional reservoir consists of "tight" clastic lithofacies of mostly Lower Pontian located on the north-eastern margin of the subdepression. These are fine-grained sandstones with frequent alternations in siltites, silty and clayey sandstones. They are located on secondary migration pathways, but were never evaluated as regional reservoirs, although numerous drilling tests showed gas "pockets".

Keywords: hydrocarbon gas; unconventional reservoirs; drilling; Neogene; Croatia

\section{Introduction}

The main general background for this research is the fact that the era of oil and gas as dominant energy sources will not be obsolete in the next human generation. The role of renewable energies, generated by wind, Sun or tide, will be more and more important and their share in total production will probably reach $20-30 \%$ in many countries. The main reason for their growth is tax policy, supporting clean or "green" energy sources to decrease atmospheric pollution and the danger to the environment. Such a danger is relatively the highest for coal and nuclear based power plants, processing or transport. Unconventional reservoirs of hydrocarbon gases chemically contain the same gases as in the conventional reservoirs. In fact, it can be claimed that such "unconventional" gas reserves remained trapped in the source rocks where they were generated and later mostly migrated into more permeable rocks. The second unconventional source of such gas is reservoir rocks where the hydrocarbons migrated, but generally they are rocks of marginally low permeability and porosity for them to be considered as a reservoir. In both cases, especially in the second, the recovery of such gas does not demand large additional costs, because the unconventional reservoirs are often located in the same field alongside conventional reserves.

Moreover, as a second claim, unconventional reservoirs can often be accompanied by deep geothermal sources, especially where hydrocarbon reservoirs are in high-temperature zones (late catagenesis, metagenesis). Such geothermal energy could be directly used for an electrical power plant. However, numerous geothermal reservoirs are available worldwide 
at low-medium temperatures. Such sources could be used through the installation of smallsize power plants providing power or heat-applying Organic Rankine Cycles technology [1], where high efficiency could be reached with working fluid in the tubes side. In fact, the optimal combination of fluid, layout and polymer could save $73 \%$ of evaporator costs [1].

Economic optimisation of Organic Rankine Cycles for the exploitation of low to medium enthalpy geothermal brines has been explained, e.g., in [2]. The developed tools allowed for a techno-economic analysis with numerous scenarios of production from geothermal reservoirs with temperatures in the range of $120-180{ }^{\circ} \mathrm{C}$, reaching the optimum temperature for the number of cycles and fluid types, which lead to the minimal electricity production costs. Supercritical cycles, fluids with a critical temperature slightly lower than the reservoir temperature, resulted in minimal expenses [2].

At a time when oil and gas production in Croatia, from onshore and offshore fields, is continuously decreasing and energy needs are growing, the development of small unconventional reservoirs can be a very important agenda for energy policy. At least, the new gas reserves and their production increase national energy stability and decrease the dependence on imported gas. Moreover, well known technology for oil and gas production from the unconventional reservoirs and years of practice in Croatia make gas production possible from considered unconventional reservoirs, which easily increase the total proven hydrocarbon reserves, decrease future drilling, completion and production costs for such reservoirs types, as well as the price of the gas on the domestic market.

\section{Methods}

The methods in this analysis could be divided into majorly qualitative and minorly quantitative. The potential unconventional reservoirs, in the researched area, are presented mostly qualitatively using geological descriptions, regional stratigraphy and qualitative data obtained by cited sources, such as core and log tests, mapping and structural interpretation. The same approach is applied for the description of potential petroleum development of such a reservoir system, mostly on drilling types and procedures. The main qualitative part, also originally created for this research, was petrological analysis and interpretation. The representative samples were selected describing potential clastics reservoir units, conventional as well as unconventional.

The quantitative data represent the geochemical variables, putting them in the context of structural and depositional frameworks. They were especially important for one of the main qualitative achievements of this work, expressed as a hydrocarbon migration map in the analysed subdepression.

\section{Geological Properties of the Neogene Source and Reservoir Rocks in the Bjelovar Subdepression}

The crucial condition for thermogenic generation of oil, gas and condensate is the existence of a subsurface system, which consists of several geological categories, and defining recoverable reserves. Such a system is often called a "hydrocarbon system" or "petroleum system". Those geological categories represent specific rock types in the subsurface, mechanism and time responsible for fluid migration. Essentially, five of them could be outlined: trap, reservoir, source rocks, migration and hydrocarbon preservation (see Figure 1). Inside the analysed Bjelovar Subdepression, all are defined in Neogene and Quaternary sediments and divided into several lithostratigraphic and chronostratigraphic units (see Figure 1) with clearly defined ages [3,4]. Although the source, reservoir and isolator rocks range from Lower Badenian to Upper Pontian age, the main source interval is linked to Middle to Upper Badenian, and the dominant reservoir/isolator sequence is a sandstone/marl alternation of Upper Pannonian and Lower Pontian. 


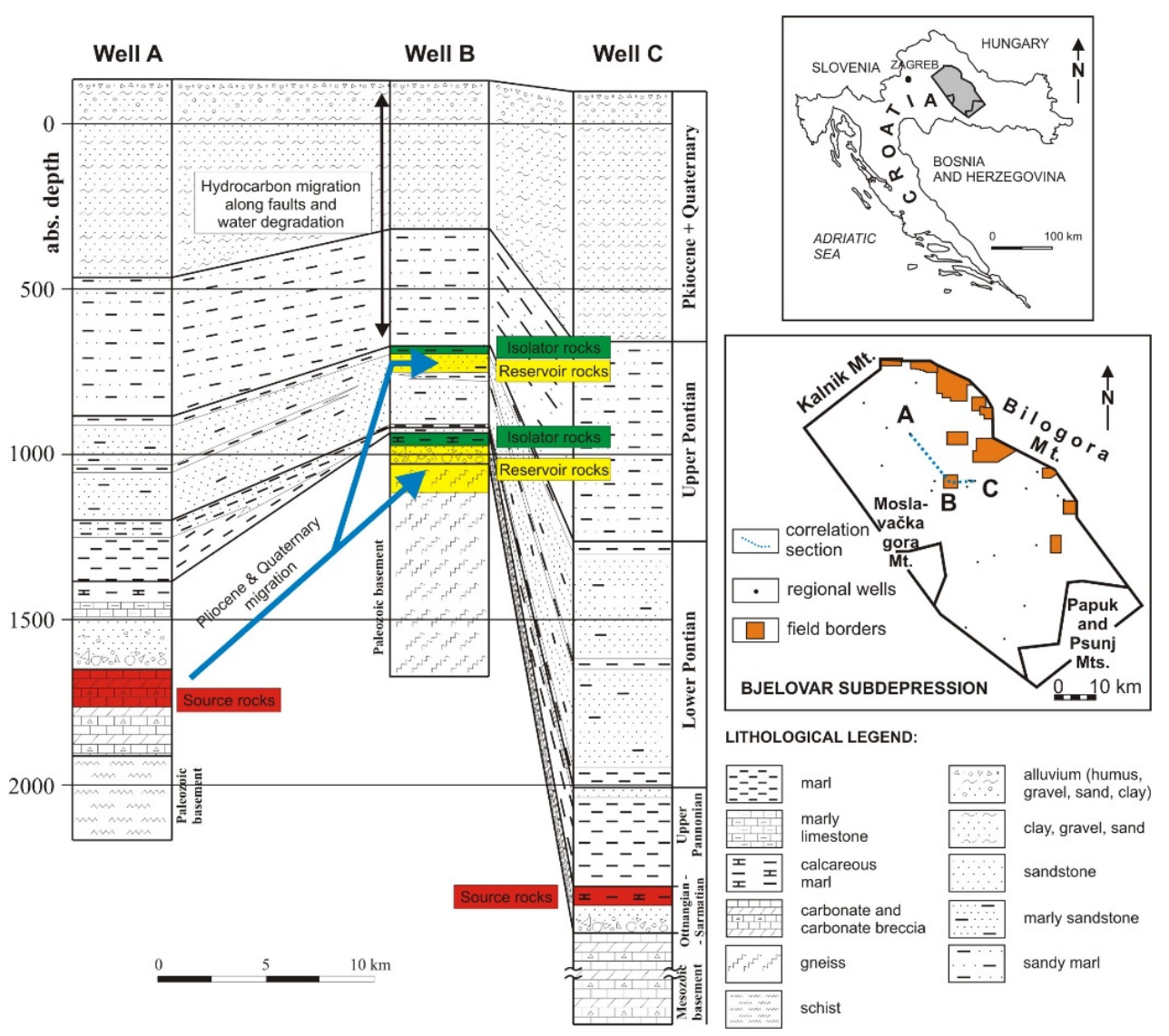

Figure 1. Location and typical hydrocarbon system in the Bjelovar Subdepression [5-7].

The conventional approach considers reservoirs as the rocks with reservoir properties, where effective porosity and permeability make hydrocarbon recovery possible. Due to wettability, capillary forces and saturation, part of the total hydrocarbon reserves (original hydrocarbons in place, abbr. OHIP) can be recovered from the reservoirs. Source rocks are considered as the place where hydrocarbons are generated mostly through a period of catagenesis. Migration from source to reservoir rocks is crucial for the accumulation of oil and gas in the trap, which can be divided into primary and secondary migration. Primary means migration inside the source rocks, which is initiated by capillary forces and pressure. Secondary migration comprises permeable pathways, gravitational separation and trapping. The length of the first one is on a scale of hundreds of metres, and the second is on a kilometre scale.

Here, both kinds of possible unconventional gas reservoirs are analysed inside the subdepression, from the group of weakly permeable sandstones and siltstones where gas is accumulated by secondary migration, but also source rocks where hydrocarbons are generated. Both types are strongly connected with migration. So, in order to evaluate them, it was also necessary to evaluate source rock potential inside the subdepression, migration pathways inside and outside the area, and possible unconventional source reservoirs as a secondary target. Possible source chronostratigraphic units are Badenian to Lower Pannonian pelitic rocks. They lithostratigraphically belong to the Mosti and Križevci Members of the Moslavačka Gora Formation (see Figure 1), and they are regionally proven as mature source rocks in the Croatian part of the Pannonian Basin System (CPBS). Five geochemical variables were studied, as follows: Corg (organic matter content), S2 (genetic potential), HI (hydrogen index), OI (oxygen index) and Ro (vitrinite reflection). Their thermal maturity was also calculated and compared with regional geothermal maps. Possible "tight" sandstone reservoirs are younger—of Lower Pontian, even Pliocene-and belong to the Poljana and Pepelana Sandstones of the Kloštar Ivanić Formation. 
Large quantities of hydrocarbon remained in reservoirs due to irreversible saturation or due to the high content of water in production. Some average recoveries are about $60 \%$ for gas and $20-30 \%$ for oil reservoirs, but not all generated hydrocarbons are expelled from the source rocks. It depends on the quality of the organic matter, natural fracturing of the source rocks and on the pressure gradient. Part of these volumes can be recovered, using artificial fracturing of rocks. The major problem in this procedure is the complex calculation of well drainage radius because rock permeability is distributed highly stochastically and often clustered. Despite the technological problems and uncertainties in reserve calculation, the total thickness of source and "tight" rocks in the entire hydrocarbon system can be considerable. Here, an example from the Croatian part of the Pannonian Basin System (CPBS), i.e., the area of the Bjelovar Subdepression, is given as a part of the Drava Depression.

\subsection{Petrological and Sedimentological Properties of Outcrop and Subsurface Rocks}

Characteristic Neogene sedimentary rocks from the surface outcrops in the wider research area (see Figure 2a-f) are presented as potential source rocks and collectors of hydrocarbon gas in the west of the Croatian part of the Pannonian Basin System (CPBS) (e.g., [7-11]). These are the Middle and Upper Miocene fine-grained marls (see Figure 2a,b), middle coarse-grained sandstones and calcarenites (Figure 2c,d), and coarse-grained clastics (see Figure 2e,f).

Properties of characteristic sedimentary rocks from the subsurface are shown as well (see Figure 3a-h). They comprise fine-grained sedimentary rocks (see Figure $3 a-d$ ) as the potential source rocks: interlaminated marlstones and siltites/shales, laminated calcitic shales, lithic greywacke sandstones to mudstones and silty marlstones as well, all enriched in kerogen in various amounts. Potential collectors determined in the subsurface are mainly coarse and middle coarse-grained sedimentary rocks (see Figure 3e-h): lithic and quartz arenitic sandstones, calcarenites and calcarenitic sandstones, and various types of petromictic conglomerates as well.

Interlaminated black globigerinid marlstone and pale grey sandy siltite/shale (see Figure 3a). Black marlstone laminas are enriched in kerogen and contain fine angular quartz grains and micas, as well as small planktic foraminifera. Pale grey sandy laminas contain angular quartz grains and lithic fragments, bound together with calcite cement. It is interpreted as the final sandy and pelitic intervals ( $\mathrm{Td}$ and $\mathrm{Te}$ ) of Bouma turbiditic sequence deposits and considered as a potential source rock for kerogen maturation and hydrocarbons generation (so-called "oil shale"). This sample was taken around the $3500 \mathrm{~m}$ subsurface depth interval.

Dark grey, laminated dense marlstone to calcitic shale (see Figure 3b) containing a thin interchange of clayey-calcitic laminas and laminas with mica flakes and fine quartz grains, tightly packed due to compaction and burial diagenesis. This sample was taken around the $1500 \mathrm{~m}$ subsurface depth interval.

Dark grey, fine-grained silty lithic greywacke sandstone to mudstone (see Figure 3c) containing fine angular quartz grains and various lithic fragments, floating within clay and silty matrix. This sample was taken around the $1000 \mathrm{~m}$ subsurface depth interval.

Well-lithified, pale grey to brown silty marlstone, enriched in kerogen (see Figure 3d) containing abundant globigerinid foraminifera skeletons, as well as some pyrite grains developed in diagenesis. This sample was taken around the $3500 \mathrm{~m}$ subsurface depth interval.

Middle coarse-grained, well-sorted lithic arenite sandstone (see Figure 3e) containing predominantly angular quartz grains and lithic fragments of quartzites, cherts and sandstones, densely packed and intercalated with mica flakes. Intergranular spaces are partly filled with microcalcite cement. This sample was taken around the $3500 \mathrm{~m}$ subsurface depth interval. 

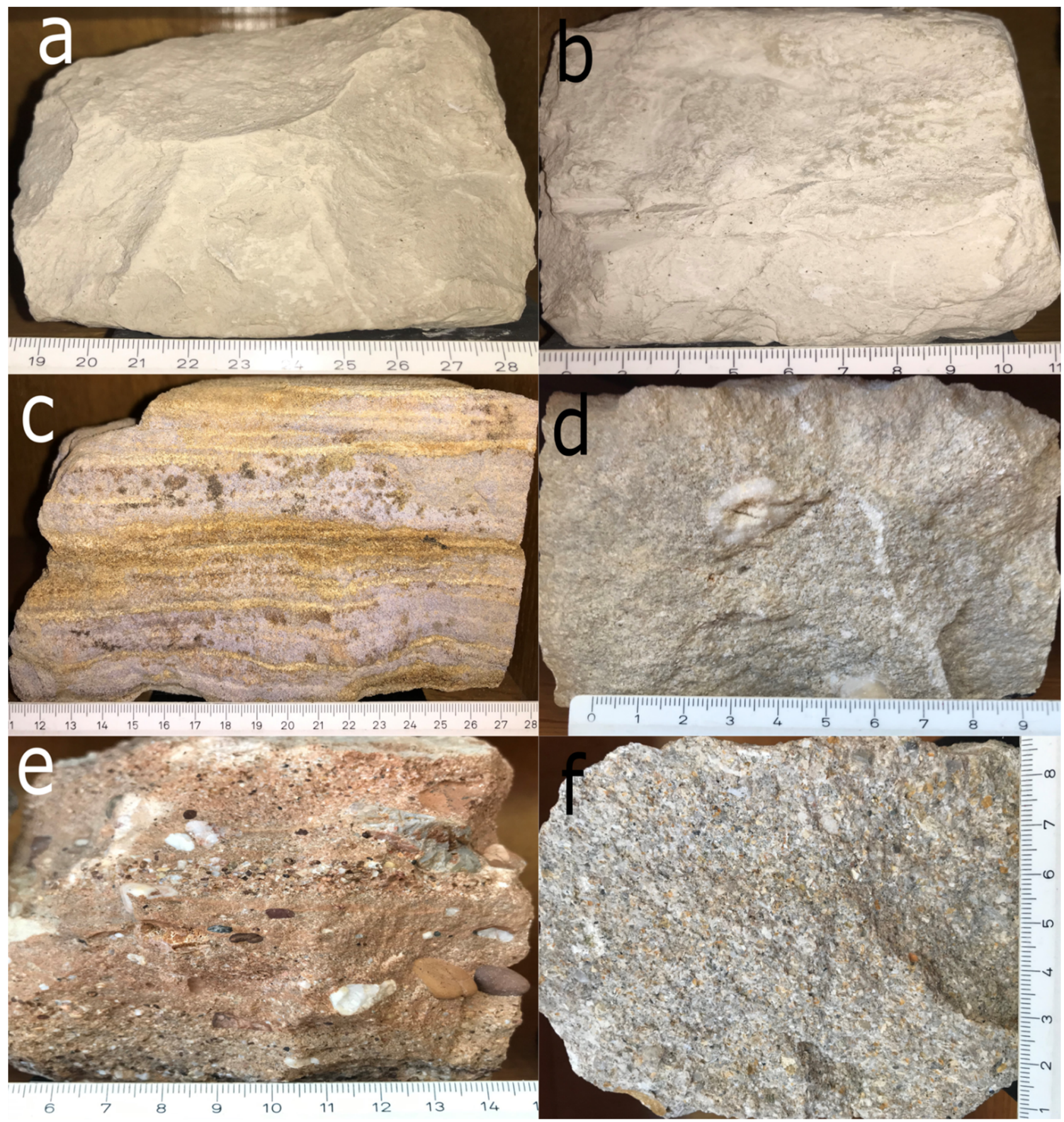

Figure 2. (a-f). Specimens of the characteristic Middle and Upper Miocene sedimentary rocks taken from the surface outcrops: (a, b)—marls; (c)—laminated sandstone; (d)—calcarenitic sandstone; (e)—interlayered conglomerate and sandstone; (f) - coarse-grained calcarenitic sandstone to fine-grained conglomerate. Samples are taken from the surface, at localities: SW Medvednica Mt. (a, d, e); SE Medvednica Mt. (b); Jerovec (c); Breznički Hum (f); all at the western margin of the CPBS. All samples are from the referent and demonstrational Minerals and Rocks Collection, situated at the Department of Mineralogy, Petrology and Mineral Resources (Faculty of Mining, Geology and Petroleum Engineering, University of Zagreb). 


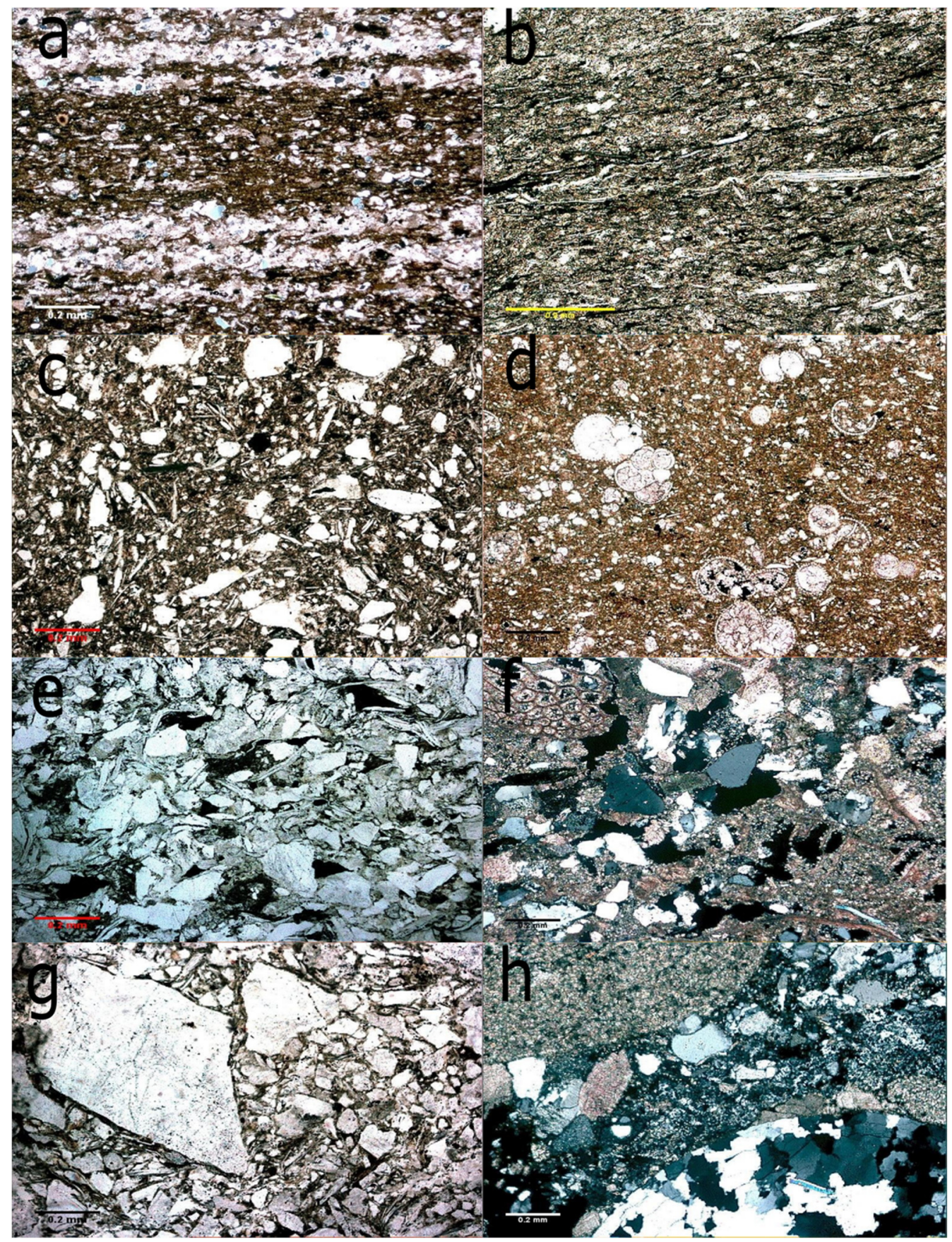

Figure 3. (a-h). Microphotographs of the characteristic source rocks and collectors taken from the subsurface samples (scale bars $=0.2 \mathrm{~mm}$ ). (a-d)—source rocks (marlstones, siltites and shales); (e-g) - collectors (sandstones, calcarenites and conglomerates). Samples are taken from the subsurface at localities Mosti $(\mathbf{b}, \mathbf{d}, \mathbf{f})$, Fančev mlin $(\mathbf{a}, \mathbf{c}, \mathbf{g})$, and Mičetinac $(\mathbf{e}, \mathbf{h})$ in the Drava Depression.

Fossiliferous lithic arenite sandstone (see Figure 3f) contains fine-grained, semiconsolidated, grey semi-calcareous sandstone, which includes predominantly siliciclastic grains (quartz and metamorphics) and subordinate fossil detritus (bryozoans and bivalves), also having laminated micas and randomly dispersed glauconitic grains, bound together in calcite cement. This sample was taken around the $1000 \mathrm{~m}$ subsurface depth interval.

Coarse-grained, densely packed, clast-supported lithic arenite sandstone to petromictic breccia/conglomerate (see Figure 3g) containing poorly sorted, angular lithic fragments of metamorphics and quartz grains, together with micas and some feldspars. Intergranular spaces are partly filled with fine marly matrix, and grains are bound together with 
cryptocrystalline calcite cement. This sample was taken around the $3500 \mathrm{~m}$ subsurface depth interval.

Well-lithified, clast-supported petromicitic conglomerate (see Figure 3h) containing well-rounded clasts of various rocks (magmatics, metamorphics and dolomites), bound together in sandy matrix of various angular grains, together with dispersed glauconitic grains and mica flakes. This sample was taken around the $3000 \mathrm{~m}$ subsurface depth interval.

\subsection{Geochemical Values in the Source Rocks}

In the analysed area, as well as in the entire CPBS and the Pannonian Basin System (PBS) in general (e.g., [11-15]), from the Upper Badenian to the Lower Pannonian age, characteristic sedimentation of pelitic rocks, such as marlstone, limestone, calcitic marlstone and marly limestone, prevailed. The mostly shallow, calm, and brackish environment favoured the preservation of organic matter and its transformation into kerogen. Such a transformation was mostly unsuccessful due to the relatively small depths in the subdepression (today less than $3000 \mathrm{~m}$ ), but where it was effective, kerogen of types II and III were formed. The generation potential of source rocks is described by geochemical variables (see Table 1). It is clear, that Middle Miocene pelites can be considered as regional weak source rocks, mostly due to very low average carbon content (low margin for clastic source rocks for generation is about $0.5-1.0 \%$, which is similar to the subdepression's mean value). Moreover, the organic carbon content is very variable, from 0.31 to $7.28 \%$ (the means are given in Table 1$)$. Higher values of $\mathrm{HI}\left(\mathrm{S}_{2} / \mathrm{C}_{\text {org }}\right.$, i.e., $\left.\mathrm{mg} \mathrm{HC} / \mathrm{g} \mathrm{C}_{\text {org }}\right)$ indicate that samples could be taken locally with significant hydrocarbons obtained during laboratory pyrolysis $\left(420-460^{\circ} \mathrm{C}\right)$. Generally, though, organic matter is shallow and oxidated, showing high values of $\mathrm{OI}\left(\mathrm{S}_{3} / \mathrm{C}_{\text {org }}\right.$, i.e., $\left.\mathrm{mg} \mathrm{CO}_{2} / \mathrm{g} \mathrm{C}_{\text {org }}\right)$-Figure 4.

Table 1. Geochemical variable values in potential source rocks in the Bjelovar Subdepression, Croatia [16].

\begin{tabular}{|c|c|c|c|c|c|c|}
\hline Variable & Mean & $-95 \%$ & $95 \%$ & Minimum & Maximum & Variance \\
\hline \multicolumn{7}{|c|}{ Badenian and Sarmatian rocks (16.4-11.5 Ma) } \\
\hline $\begin{array}{c}\mathrm{C}_{\text {org }} \\
(w t \%)\end{array}$ & 1.14 & 0.15 & 2.14 & 0.01 & 5.3 & 2.2 \\
\hline $\begin{array}{c}\mathrm{S}_{2} \\
\text { (pyrolytic peak mg HC/g rock) }\end{array}$ & 6.91 & 0.00 & 19.17 & 0.01 & 22.91 & 97.4 \\
\hline $\begin{array}{c}\text { HI } \\
\text { (mg HC/g org. C) }\end{array}$ & 237.81 & 45.67 & 429.94 & 120.00 & 397.78 & $14.6 \times 10^{3}$ \\
\hline $\begin{array}{c}\text { OI } \\
\text { (mg CO} 2 / g \text { org. } \mathrm{C})\end{array}$ & 447.83 & 0.00 & 1851.32 & 107.30 & 1100.00 & $3.2 \times 10^{5}$ \\
\hline \multicolumn{7}{|c|}{ Upper Pannonian rocks (11.5-9.3 Ma) } \\
\hline $\begin{array}{c}\mathrm{C}_{\text {org }} \\
(w \mathrm{w} \%)\end{array}$ & 0.61 & 0.35 & 0.87 & 0.19 & 1.41 & 0.11 \\
\hline $\begin{array}{c}\mathrm{S}_{2} \\
\text { (pyrolytic peak mg HC/g rock) }\end{array}$ & 1.64 & 1.07 & 4.34 & 0.92 & 2.89 & 1.18 \\
\hline $\begin{array}{c}\text { HI } \\
\text { (mg HC/g org. C) }\end{array}$ & 271.74 & 0.00 & 619.11 & 184.0 & 433.0 & $19.6 \times 10^{3}$ \\
\hline $\begin{array}{c}\text { OI } \\
\text { (mg CO} / \text { /g org. } \mathrm{C})\end{array}$ & 76.70 & 0.00 & 650.64 & 31.53 & 121.87 & 4080.66 \\
\hline
\end{tabular}

As kerogen type III (terrigenous material from the higher plants) predominates, hydrocarbon generation mostly produced gas with an efficiency of usually less than $20 \%$, where the main process happened at $120-150{ }^{\circ} \mathrm{C}$. Such a temperature range had been proven on the single deep locality inside the depression, in the Velika Ciglena or Eastern Bjelovar Syncline, where catagenesis occurred before approx. 4.5 Ma, and "oil windows" were activated in the last $0.2 \mathrm{Ma}$ [16]. Moreover, generation in leaner source rocks is a less efficient process, and most of the created hydrocarbons remain inside, especially oil [17]. The thickness of the source intervals rich in organic carbon inside the subdepression is 
mostly a few metres, so the efficiency of expulsion is low and most of the generated gas probably remained within the source facies.

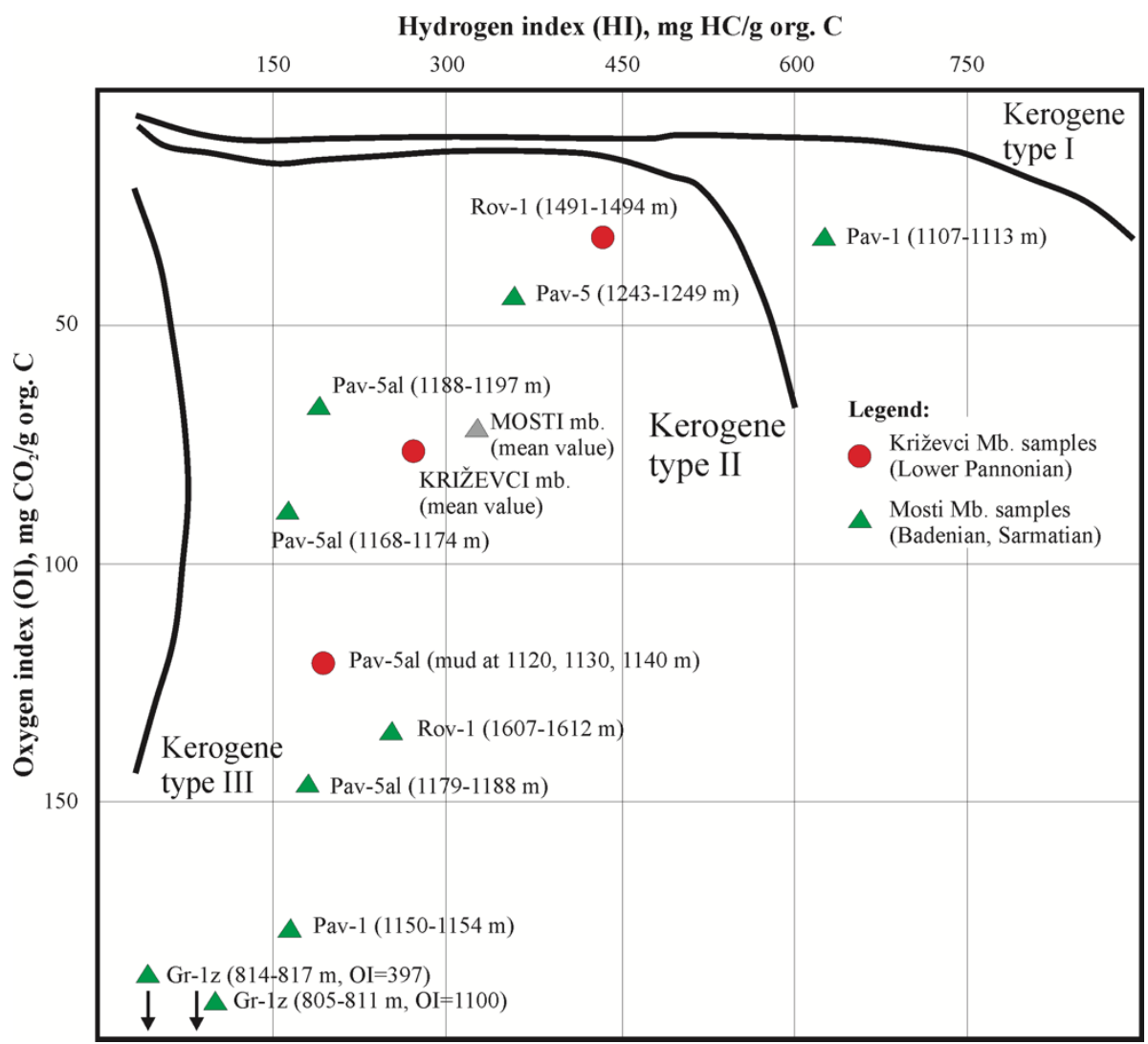

Figure 4. Van Krevelen diagram of kerogen samples. The Bjelovar Subdepression, Croatia [16].

\subsection{Migration Pathways}

Migration occurrence and pathways are the critical factors for the creation of any conventional as well as weakly permeable reservoirs (conditionally permeable clastics such as fine-grained silty sandstones and siltstones). The fluid physics directionally depend on permeable migration zones in the subsurface as well as geothermal gradients, i.e., subsurface temperatures (hydrocarbon generation "per se", but also the heating of subsurface fluids). The Bjelovar Subdepression belongs to the hotter part of the Pannonian Basin System. The authors of [18] and [19] showed that geothermal gradients vary between 4.5 and $7.7^{\circ} \mathrm{C} / 100 \mathrm{~m}$.

Inside the subdepression, the locally developed source rocks are mudstones, shales, and siltites of Badenian to Lower Pannonian age, appearing from 811 to $3255 \mathrm{~m}$ depth, and they are mostly thermally immature. In deeper, predominantly clastic rock sequences, high thermal altered terrestrial organic matter appears, which presently would reach the late catagenesis and early metagenesis stage (according to Figure 5). They are, in fact, still currently in the early catagenesis stage, due to a lower gradient in the past. Such areas are the Velika Ciglena Syncline and marginally Western Bjelovar or Rovišće Synclines (see Figure 1, well A) and Eastern Bjelovar or Velika Ciglena Synclines (see Figure 1, well B). There was not enough volume to feed all the discovered hydrocarbon reservoirs, even only to saturate them with gas. So, the proposed migration map for the subdepression is given in Figure 5. 


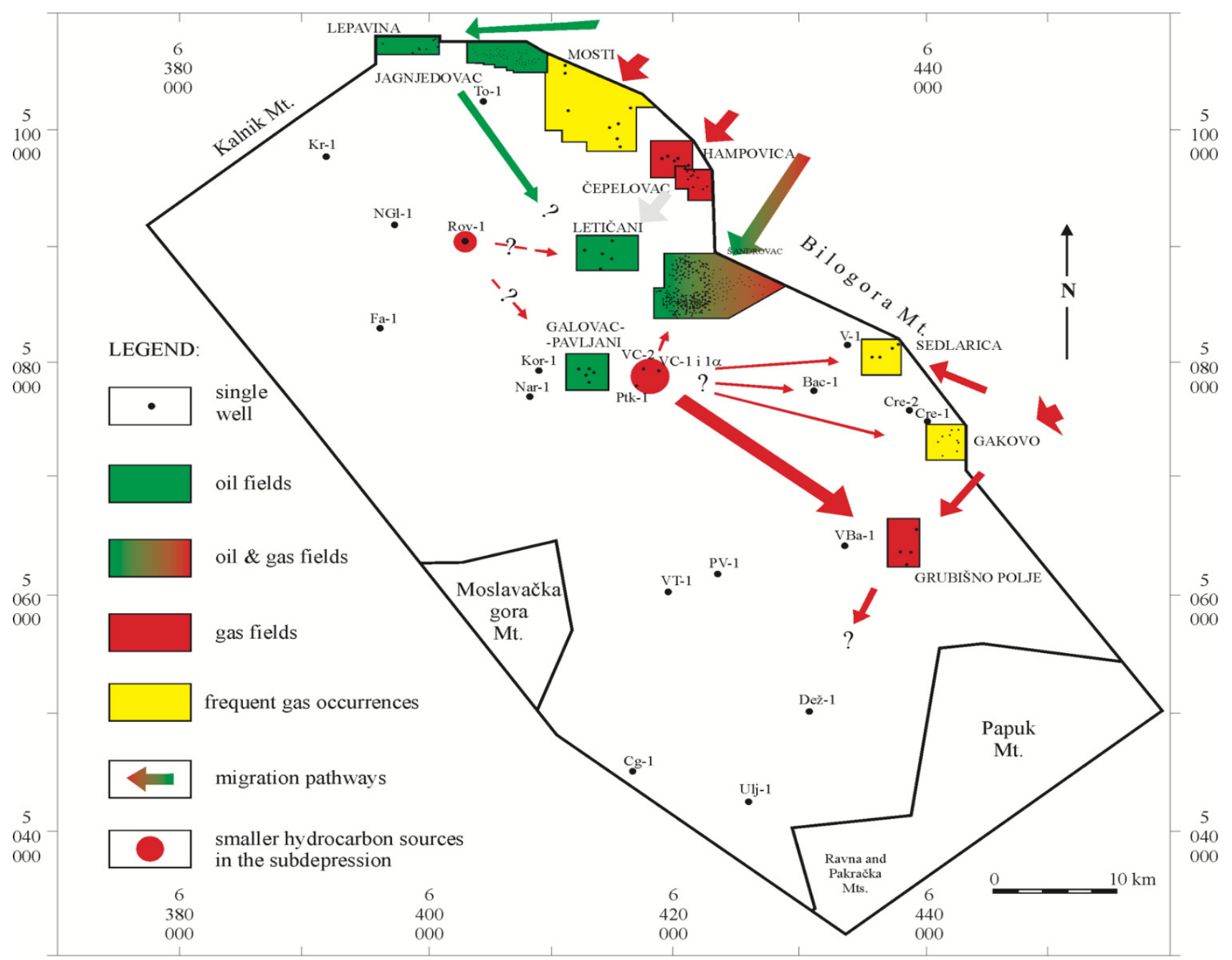

Figure 5. The proven and assumed hydrocarbon migration pathways for fields and occurrences inside the subdepression.

It is obvious that, besides several smaller fields, there are several localities with proven gas occurrences, but they are not yet in production, situated on the north-northeastern margin of the subdepression. The reasons are relatively small possible estimated reserves, based on the low gas saturation and/or small porosities/permeabilities as a result of numerous alternations of the "tight" sandstone lithofacies. Such possible producing horizons are situated at depths of 800 to $1000 \mathrm{~m}$, with a predominance of weakly permeable sandstones of Upper Miocene age.

From a geochemical point of view, some parameters indicate high-quality paraffinic oils, originating from a terrestrial precursor, which is also confirmed by carbon isotopic ratios with a slight predominance of light isotope $12 \mathrm{C}(>\delta 13 \mathrm{C}-25.1 \%)$. There is also proven oil where bimodal hydrocarbon distribution reflected both sapropelic and terrestrial origin. The larger differences in physical and chemical properties of hydrocarbons can be attributed to differences in source facies type and maturity, but post-generative processes, particularly subsurface water washing, water flooding and evaporative fractionation, also altered them.

Reservoir gases could be wet with a concentration of higher hydrocarbon homologs (about $2-22 \%$ ), but much more importantly, they could be represented by migrated thermogenic gases associated with oils or mixed gases (bacterial/thermogenic sources) in shallow reservoirs. They are the promising unconventional targets where some migration could form significant gas occurrences in "tight" lithofacies of Upper Miocene, even Lower Pliocene. Such rocks are proven in the north-eastern part (see Figures 1 and 5, localities 3, 9, 
10) and are saturated with gasses, which have slightly lower wetness and higher maturity than gasses in the western part of the subdepression.

The crucial variable in such reservoirs is porosity, i.e., permeability. For example, from 20 to $25 \%$ in conventional reservoirs in weakly permeable sandstones, tight sands or sandy marls of Upper Miocene, it can be reduced to about 10\% (e.g., 12.86 on locality A, 12.03 on $B$ or $6.14 \%$ on C, Figure 1). Consequently, the permeability is reduced to less than $10^{-3} \mu \mathrm{m}^{2}$ (or 1 millidarcy). As an example, a qualitative representation of sudden and often changing lithofacies from medium-grained sandstone into marly sandstone and vice versa is given in Figure 6, where Poljana Sandstone represents a typical regional proven reservoir rock sequence of Lower Pontian (Upper Miocene) age.

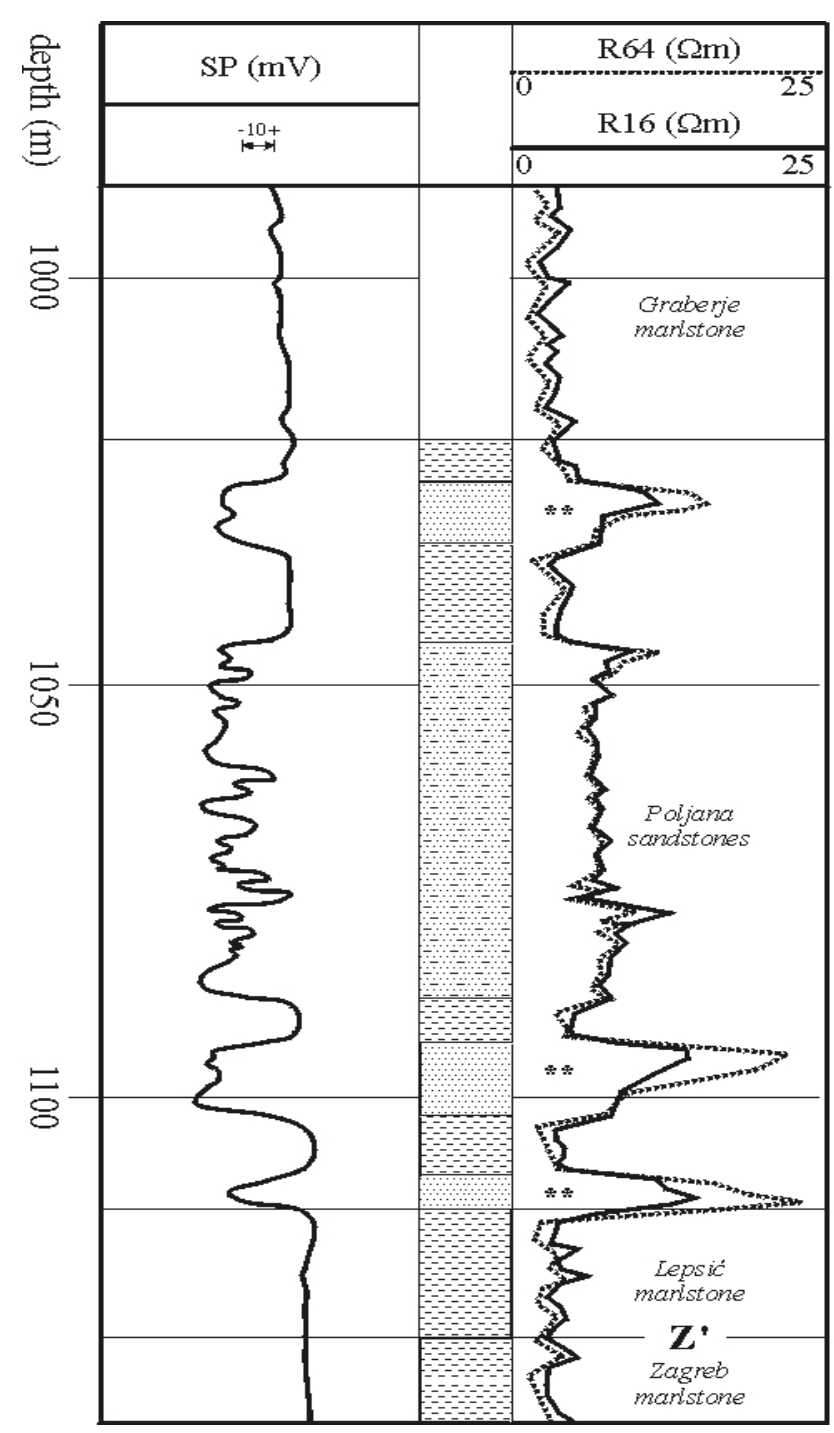

Legend:

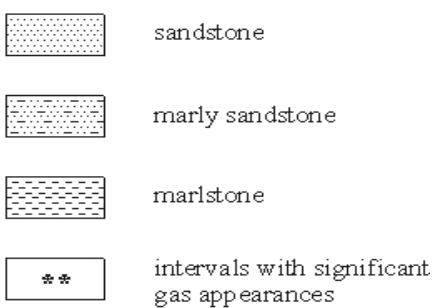
gas appearances

Figure 6. Sudden changes between medium-grained and marly sandstone layers inside a single lithostratigraphic member showed qualitatively on SP/R e-logs.

For such lithofacies [20], a numerical analysis of possible regional porosity-based $\log$ resistivity curves was performed. The Cremušina Structure (locality no. 10, Figure 5) is selected on the north-eastern part of the subdepression. The results outlined that in the alternation of fine-grained sandstones with silty marly sandstones, i.e., in a section considered as an unconventional potential reservoir, regionally can be described with a porosity of about $10 \%$. That is high enough to support gas migration and form smaller "tight" gas reservoirs. 


\subsection{Geothermal Potential of the Investigated Area}

According to the characteristics of the investigated area, the possibility of finding a geothermal potential is in geopressured reservoirs. The hydrostatic pressure is proportional to the weight of water and increases with depth. From the aspect of geothermal exploitation, geothermal reservoirs are characterized by three important properties [21]: high pressure, high temperature, and dissolved methane. The CPBS has the greatest geothermal potential, as well as significant technological opportunities for the exploitation of geothermal energy in agriculture and the food industry. The average geothermal temperature gradient in the CPBS is $0.049{ }^{\circ} \mathrm{C} / \mathrm{m}$ [22], while in the rest of Europe it is $0.03{ }^{\circ} \mathrm{C} / \mathrm{m}$ [23]. Data on geothermal reservoirs were obtained from exploration wells that were primarily intended for locating oil and gas reservoirs. Great potential for the exploitation of geothermal energy is found in negative oil and gas wells, then in mature oil and gas reservoirs as well as in aquifers. Geothermal deposits in the Republic of Croatia (see Figure 7) are divided according to the temperature of geothermal liquid at the wellhead into [24] reservoirs with a temperature higher than $100{ }^{\circ} \mathrm{C}$ and reservoirs with a temperature lower than $100{ }^{\circ} \mathrm{C}$.

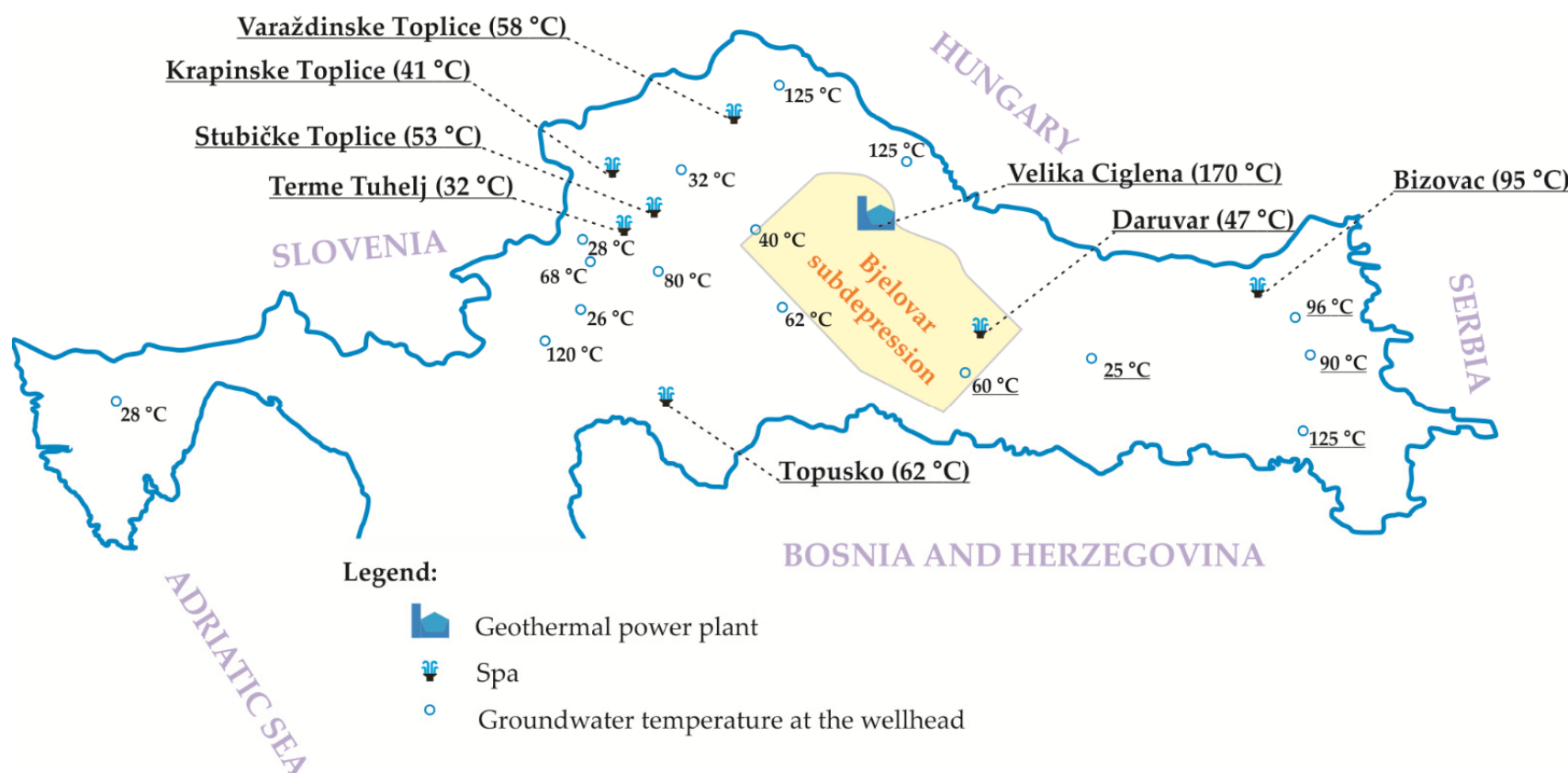

Figure 7. Temperature values in proven geothermal reservoirs modified after [25].

According to the authors of [26,27], the possible thermal power from geothermal energy is between $750 \mathrm{MW}_{\mathrm{t}}$ and 1,300 $\mathrm{MW}_{\mathrm{t}}$ for the CPBS area. In the researched area of the Bjelovar Subdepression, the geothermal field Velika Ciglena was put into production in 2018. The installed capacity of the geothermal power plant Velika Ciglena is $>16.5$ MWe [28].

\section{Challenges and Solutions for Drilling in Clastic Alternation of Conventional and Unconventional Reservoirs}

Due to the specific properties of the unconventional reservoirs, their development cannot be successfully completed without the application of two well-known technologies in drilling and completion operations, horizontal drilling, and multi-stage hydraulic fracturing. Moreover, some relatively rarely used technologies for conventional reservoirs, such as natural dump flooding wells [29], could be considered in low-permeable sandstone lithofacies, in the late recovery phase.

The horizontal drilling technology allows petroleum companies to economically develop different types of reservoirs which have hitherto been unprofitable or out of reach. 
Despite highly developed different techniques and technologies in the petroleum industry, the development of the unconventional reservoirs demands the adjustment of these commercial techniques and technologies to the specificities of the unconventional reservoirs [30]. As in the case of the development of conventional oil and gas reservoirs, the success of unconventional reservoir development, especially drilling and completion activities, distinctly depends on the available data. Some well investigated areas, where significant oil and gas production from conventional reservoirs exist together with unconventional reservoirs, were neglected at first and, thus, insufficiently researched.

Drilling and completion campaigns in unconventional reservoirs, as well as subsequent oil and gas production, depend on the available data about lithology, pore pressure and in situ stress distribution in the areas under consideration. This information is very important from a geomechanical point of view, especially for engineering demanding operations, such as horizontal drilling or hydraulic fracturing [31]. Building a mechanical earth model (MEM) for the specific underground location based on the available seismic data and proper calibration should be a starting point in the development of any unconventional reservoirs. The mentioned model includes a 1-3D structural model, mechanical stratigraphy, elastic properties, and strength parameters, as well as earth stress (magnitude and direction) and pore pressure. Moreover, improvement in any visualisation, such as advance mapping [32], is a useful addition to such a model, outlining unconventional lithofacies and their structures. A high-quality mechanical earth model would be very useful in the planning stage, and it would significantly reduce operational risks, time, and costs. The available information from the earth model for petroleum systems directly affects the successful development of unconventional reservoirs [33], and this emphasizes the importance of geochemical data, especially from the Middle Miocene source lithofacies.

A well-developed mechanical earth model represents a starting point (input) for wellbore stability analyses. During the drilling operation, stress redistribution takes place in the vicinity of the wellbore wall, whereby in situ stresses (vertical, maximum, and minimum horizontal) are replaced with axial, radial and hoop stresses. Aside from stress redistribution along the wellbore wall, the wellbore stability strongly depends on the wellbore orientation (inclination and azimuth) and the existence of different specific circumstances such as anisotropy, heterogeneity, the existence of fractures, faults, etc. In some circumstances, alternation in pore pressure and rock properties require the application of a specific drilling technique, such as managed pressure casing drilling (MPCD) or managed pressure cementing (MPC), which involve a closed-loop mud circulation system and carefully balancing pore pressure during the entire drilling operation [34]. In the presented analysis, the stability of the unconventional series would not be problematic in Badenian to Lower Pannonian source lithofacies, due to the high level of consolidation. It is valid both for carbonates as well as clastics (sandstones and marls). In all such permeable lithofacies (lime breccia, coarse-grained sandstones), conventional hydrocarbon reservoirs are already proven (Letični, Galovac-Pavljani and Grubišno Polje structures; Figure 5). However, such stability could be significantly less during drilling in low-permeable sandstones on the north-eastern margin of the explored subdepression (Mosti, Sedlarica, Gakovo structures; Figure 5). Such lithofacies are significantly more weakly consolidated, especially ones determined at the very end of Lower Pontian or in Upper Pontian. Consequently, the stability breakdown or even "sand flows" into the wellbore could occur.

Unlike the development of conventional reservoirs, the development of an unconventional reservoir usually requires horizontal wells with a long horizontal section properly placed in the space, which implies the use of some advanced drilling technology such as measurement while drilling (MWD), logging while drilling (LWD) or geosteering and a different completion design with multistage hydraulic fracturing. The completion design of a well in an unconventional reservoir includes one of the following solutions: cased and cemented hole, open hole completion, hole cased with perforated casing and cemented casing with stimulation sleeves [35]. 
Another risk associated with unconventional reservoirs is, as previously mentioned, possible rock damage problems. It is more pronounced in unconventional lithofacies (than in conventional ones) because of well construction, often with a long horizontal open hole section through the reservoir. The unconventional lithofacies are characterized by low porosity (here less than $10 \%$ ) and a pore throat $(10-1000 \mathrm{~nm}$ ) which makes most of the filtration control additives (size in $\mathrm{mm}$ and $\mu \mathrm{m}$ range) inapplicable [36]. Drilling fluid invasion within a near-wellbore zone can cause a pore pressure change and wellbore instability problems as a result of a physicochemical reaction between the drilling fluid filtrate and clay minerals, especially in presented marls of Middle Miocene. This process can be accelerated in the presence of natural or induced fractures, as observed in the subdepression along structures closer to main fault zones. Recent developments in drilling fluid technology involve the application of smart drilling fluids in combination with nanoparticles and the application of environmentally acceptable water-based drilling fluids in the drilling of unconventional reservoirs [37].

Generally, several techniques can be applied for the evaluation of drilled, completed and stimulated wells such as production logging, proppant tracers, fluid tracers, hydrocarbon tracer, microseismic, distributed temperature survey (DTS) and distributed acoustic survey (DAS) [38]. During production logging, it is possible to obtain different data such as temperature, pressure, fluid density, formation fluid inflow points and the type of produced fluid. Proppant, fluid and hydrocarbon tracer, as well as microseismic, are used for full characterisation of the fractured area covered by hydraulic fracturing. The last studies indicate the possible application of unconventional nanotechnology-based tracers (Carbon Quantum Dots (CQDs), function silica nanoparticle synthesis, surface modification of upconversion nanoparticles) instead of traditional radioactive tracers [39]. Unlike conventional radioactive tracers, nanoparticles are environmentally more acceptable and have many other advantages, such as inertness, chemical stability, the formation of stable dispersion, etc. The appropriate selection of the evaluation technique can be very useful in cost reduction, completion design optimisation and production improvement. Machine learning and data mining can also be valuable tools in fluid production prediction from an unconventional reservoir, and validation of the applied completion system. All these methods could be applied for the development of unconventional reservoirs in the Bjelovar Subdepression. Unfortunately, potential unconventional reservoirs are, probably, in the range of very small $\left(<10,000 \mathrm{~m}^{3}\right)$ to small $\left(10,000-100,000 \mathrm{~m}^{3}\right)$ fields, regarding the classification of Croatian fields and recoverable reserves [40]. Consequently, many of the advance techniques would not be affordable and profitable for such reserves, and balancing between "standard" and advanced logging programs is a viable option.

\section{Discussion}

Regionally proven mature source rocks in the Croatian part of Pannonian Basin System (CPBS), mainly weakly permeable sandstones, siltstones and marls of Badenian to Lower Pontian age, are potential sources for unconventional gas reservoirs inside the Bjelovar Subdepression. Gas could be accumulated during catagenesis or by secondary migration.

Micropetrographic analysis of the characteristic sedimentary rocks from the subsurface (see Figure $3 a-h$ ) reveals their composition and fabric, suitable for kerogen maturation and hydrocarbons generation. Two groups of sedimentary rocks are distinguished, according to their potential as the source rocks or as the reservoirs of hydrocarbons, by primary or secondary migration pathways.

Predominantly fine-grained sedimentary rocks (see Figure 3a-d), mainly enriched in kerogen, are marked as the potential source rocks. These include interlaminated marlstones and siltites/shales, laminated calcitic shales, lithic greywacke sandstones to mudstones and silty marlstones. Their origin is closely related to deep-water sedimentary environments and processes in the sedimentary basin (CPBS), deposited in the basin itself (i.e., welllithified, pale grey to brown silty marlstone with abundant globigerinid foraminifera skeletons and enriched in kerogen, shown in Figure 3d), or at the distal parts of the vanning 
gravity currents from the basin margins (i.e., interlaminated black globigerinid marlstone and pale grey sandy siltite/shale, shown in Figure 3a).

Mainly coarse and middle coarse-grained sedimentary rocks are marked as potential reservoirs determined in the subsurface (see Figure 3e-h). These are lithic and quartz arenitic sandstones, calcarenites and calcarenitic sandstones, as well as various types of petromictic breccias/conglomerates. Their relatively broad grain-size range (from coarseto middle-grained clastics and calcareous clastics), as well as their various fabric (from clast-supported breccias/conglomerates, shown in Figure 3g,h) to various arenitic and greywacke sandstones (shown in Figure 3e,f), place them as, more-or-less, suitable for hydrocarbons emplacement.

Porosity ranges of potential reservoirs encourage this hypothesis. However, their permeability ranges partly limit migration pathways to secondary, including oblique/vertical migration of hydrocarbon gas during burial, from the source rocks placed at the greater burial depths in the subdepression toward the potential reservoirs at the lower depths (see Figure 1). Sedimentary sequences with thin collector units followed by seal rock units, such as sandstone and marl units appearing in the upper parts of the Upper Miocene sequences in the CPBS, make a suitable sedimentary architecture for the development and emplacement of so-called unconventional hydrocarbon gas reservoirs.

The considered unconventional reservoirs are placed in the Croatian part of the Pannonian Basin System (CPBS), an area with a long history in oil and gas production from conventional reservoirs. This fact represents the main advantage in further consideration of gas production from unconventional reservoirs because of the wells and the surface infrastructure on the existing fields in the area. The existing wells provide the possibility for additional research and the data gathering necessary for the economically and technically feasible development of unconventional reservoirs. Except for additional logging, fluid sampling and observation for downhole changes, the existing wells can be used for re-entry in horizontal drilling; thus, significantly reducing the cost of the drilling and completion of the operation.

\section{Conclusions}

Qualitative and quantitative analyses of some aspects belonging to small unconventional hydrocarbon gas potential reservoirs are given here. Potential reservoirs were analysed in the relatively isolated Neogene Subdepression in Northern Croatia, where depths are rarely larger than $3000 \mathrm{~m}$ and clastic sedimentation was dominated with pelitic detritus. As conventional discoveries were limited on several fields, the further research and investments highly depend on new discoveries, smaller but profitable. As migration pathways supported the idea that not all possible (P3), even probable (P2), reserves are proven, analysis of this type confirmed the following summarised results:

1. The deepest Eastern Syncline (also named as the Velika Ciglena Syncline), is a single place where gas was generated and migration started to feed smaller surrounding structures. The gas-prone source rocks of that structure could be studied in detail as sources of unconventional lithofacies. As there is a proven high geothermal gradient and a geothermal reservoir below the source facies, the maturation process could obviously take a long time, currently reaching early catagenesis.

2. The north-eastern margin of the subdepression is characterized with numerous structures where gas occurrences were often observed during drilling through "tight" sandstones, reaching from a small percentage up to 10 percent methane. The volume of potential unconventional reservoirs in the zone is several times larger than the reservoir in the Velika Ciglena Syncline.

3. This north-eastern margin is represented with an alternation of fine-grained with silty and marly sandstones. Consequently, porosity varies in a wide range of $10-25 \%$, but a single layer is often no thicker than $1 \mathrm{~m}$. It makes the zones hard to test and develop, due to potential instability during drilling. Moreover, logging would hardly reach 
true saturated rock values (such as for spontaneous potential or resistivity). So, any production and reserve calculation is a potentially highly uncertain task.

4. As a marginal target could be outlined for the Upper Badenian "tight" but consolidated sandstones, as sporadic unconventional Badenian lithofacies. Unfortunately, these lithofacies are still not regionally well explored and are highly uncertain regarding their unconventional potential.

5. Taking into account experience in oil and gas production on a considered area, and existing well and surface facilities, the development of a small unconventional gas reservoir in the future can be a promising solution for the growing energy demand in Northern Croatia.

Author Contributions: Conceptualization, T.M. and U.B.; methodology, T.M., U.B., B.P. and J.I.; validation, T.M., U.B., B.P. and J.I.; investigation, T.M., U.B., B.P. and J.I.; writing—original draft preparation, T.M., U.B. and B.P.; writing—review and editing, T.M., U.B., B.P. and J.I.; visualization, T.M., U.B. and B.P.; supervision, T.M.; funding acquisition, T.M. All authors have read and agreed to the published version of the manuscript.

Funding: This research was conducted as part of a project funded by the University of Zagreb "Mathematical methods in geology V" (led by T. Malvić).

Conflicts of Interest: The authors declare no conflict of interest.

\section{References}

1. Ceglia, F.; Marrasso, E.; Roselli, C.; Sasso, M. Effect of layout and working fluid on heat transfer of polymeric shell and tube heat exchangers for small size geothermal ORC via 1-D numerical analysis. Geothermics 2021, 95, 102118. [CrossRef]

2. Astolfi, M.; Romano, M.C.; Bombarda, P.; Macchi, E. Binary ORC (Organic Rankine Cycles) power plants for the exploitation of medium-low temperature geothermal sources-Part B: Techno-economic optimization. Energy 2014, 66, 435-446. [CrossRef]

3. Ldi, K. Paleoceanography and climate of the Badenian (Middle Miocene, 16.4-13.0 Ma) in the Central Paratethys based on foraminifera and stable isotope (18O and 13C) evidence. Int. J. Earth Sci. 2006, 95, 119-142.

4. Haq, B.U.; Eysinga, F.W.B. (Eds.) Geological Time Table, 5th ed.; Wall Chart; Elsevier Science: Amsterdam, The Netherlands, 1998; ISBN 0444828656.

5. Malvić, T.; Velić, J.; Peh, Z. Qualitative-quantitative analyses of the influence of depth and lithological composition on Lower Pontian sandstone porosity in the central part of Bjelovar Sag (Croatia). Geol. Croat. 2005, 58, 73-85.

6. Malvić, T.; Rusan, I. Potential Hydrocarbon Discoveries in Bjelovar Subdepression, Croatia. Search Discov. 2007, 16. Available online: https: / /www.searchanddiscovery.com/documents/2007/07098malvic/ (accessed on 11 June 2021).

7. Malvić, T.; Rusan, I. Investment Risk Assessment of Potential Hydrocarbon Discoveries in a Mature Basin, Case Study from the Bjelovar Sub-Basin, Croatia. OIL GAS Eur. Mag. 2009, 2, 67-72.

8. Malvić, T. Regional geological settings and hydrocarbon potential of Bjelovar sag (Subdepression), R. Croatia. Nafta 2004, 55, $273-288$.

9. Malvić, T. Review of Miocene shallow marine and lacustrine depositional environments in Northern Croatia. Geol. Q 2012, 56, 493-504. [CrossRef]

10. Pavelić, D. Tectonostratigraphic model for the North Croatian and North Bosnian sector of the Miocene Pannonian Basin System. Basin Res. 2001, 13, 359-376. [CrossRef]

11. Velić, J. Geologija ležišta nafte i plina (Geology of Oil and Gas Reservoir). In Faculty of Mining, Geology and Petroleum Engineering; University of Zagreb: Zagreb, Croatia, 2007; 311p. (In Croatian)

12. Royden, L.H. Late Cenozoic Tectonics of the Pannonian Basin System. In AAPG Memoir 45 (Chap. 3)—The Pannonian Basin; Royden, L.H., Horváth, F., Eds.; AAPG: Tulsa, OK, USA, 1988; pp. 27-48.

13. Rögl, F. Stratigraphic Correlation of the Paratethys Oligocene and Miocene. Mitt. Ges. Geol. Bergbaustud. Osterr. 1996, 41, 65-73.

14. Rögl, F. Palaeogeographic Consideration for Mediterranean and Paratethys Seaways (Oligocene to Miocene). Ann. Naturhist. Mus. Wien 1998, 99a, 279-310.

15. Vrbanac, B. Paleostrukturne I Sedimentološke Analize Gornjopanonskih Naslaga Formacije Ivanić Grad U Savskoj Depresiji Palaeostructural and Sedimentological Analyses of Upper Pannonian Sediments Ivanić Grad Formation in the Save DepressionIn Croatian. Ph.D. Thesis, Faculty of Natural Sciences, University of Zagreb,"Zagreb, Croatia, 1996; 121p.

16. Malvić, T. Naftnogeološki Odnosi I Vjerojatnost Pronalaska Novih Zaliha Ugljikovodika U Bjelovarskoj Uleknini [Oil-Geological Relations and Probability of Discovering New Hydrocarbon Reserves in the Bjelovar Sag]-In Croatian. Ph.D. Thesis, Faculty of Mining, Geology and Petroleum Engineering, University of Zagreb, Zagreb, Croatia, 2003; 139p.

17. Cooles, G.P.; Mackenzie, A.S.; Quigley, T.M. Calculation of petroleum masses generated and expelled from source rocks. Org. Geochem. 1986, 10, 235-245. [CrossRef]

18. Jelić, K.; Kevrić, I.; Krasić, O. Temperatura i toplinski tok u tlu Hrvatske. In Zbornik Radova, 1. Hrvatski Geološki Kongres; Croatian Geological Institute and Croatian Geological Society: Zagreb, Croatia, 1995. 
19. Jelić, K.; Pavičić, H. Heat flow and hydrocarbon reservoirs in Croatia. Nafta 1999, 50, 257-260.

20. Malvić, T.; Sučić, A.; Cvetković, M. Low permeability Neogene lithofacies in Northern Croatia as potential unconventional hydrocarbon reservoirs. Cent. Eur. J. Geosci. 2014, 6, 182-194. [CrossRef]

21. DiPippo, R. ; Geothermal Power Plants, 4th ed.; Butterworth-Heinemann: Oxford, UK, 2016; pp. 3-22. [CrossRef]

22. Tumara, D.; Kolbah, S.; Škrlec, M.; Živković, S. Korištenje resursa geotermalne energije u Republici Hrvatskoj. Nafta i plin 2019, 39, 51-56. (In Croatian)

23. Lund, H. Renewable energy strategies for sustainable development. Energy 2007, 32, 912-919. [CrossRef]

24. Bošnjak, R. GEOEN—Program korištenja geotermalne energije: Osnovni rezultati i buduće aktivnosti (GEOEN—Geothermal Energy Use Program: Basic Results and Future Activities). Hrvat. Vode 1998, 6, 363-369. (In Croatian)

25. Guzović, Z.; Lončar, D.; Ferdelji, N. Possibilities of electricity generation in the Republic of Croatia by means of geothermal energy. Energy 2010, 35, 3429-3440. [CrossRef]

26. Kolbah, S.; Škrlec, M.; Gloub, M. Kvantifikacija indiciranog geotermalnog potencijala RH za proizvodnju električne energije. Inženjerstvo Okoliša 2018, 5, 61-68. (In Croatian)

27. Tumara, D.; Pavlović, D. Geotermalna energija i njezin potencijal u vremenu energetske diversifikacije i tranzicije Republike Hrvatske. Nafta i plin 2019, 39, 53-62. (In Croatian)

28. Živković, S.; Kolbah, S.; Škrlec, M.; Tumara, D. Geothermal Energy Use, Country Update for Croatia 2019; European Geothermal Congress: Haague, The Netherlands, 2019.

29. Zadravec, D.; Brkić, V. Intelligent natural dump flooding well—Case study from the area of the western Persian/Arabian Gulf and possible application in the Croatian mature oil field Beničanci. Rudarsko-geološko-naftni Zbornik. Min. Geol. Pet. Bull. 2020, 35, 21-31. [CrossRef]

30. Kudryashov, A.; Povzhik, P. A Comprehensive Study of Unconventional Reservoirs: The Case of Rechitskoe Field Sediments of Rock Units I-III; paper SPE-201820-MS. In Proceedings of the SPE Russian Petroleum Technology Conference, Moscow, Russia, 12-14 October 2020. [CrossRef]

31. Sayers, C.; Dasgupta, S.; Gofer, E.; Hearn, R.; Koesoemadinata, A.; Sudhakar, V. Seismic Inversion for Risk Reduction in Drilling and Production in Unconventional Reservoirs; paper SPE-201530-MS. In Proceedings of the SPE Annual Technical Conference \& Exhibition, Denver, CO, USA, 5-7 October 2020. [CrossRef]

32. Šapina, M. A Comparison of Artificial Neural Networks and Ordinary Kriging depth maps of the Lower and Upper Pannonian stage border in the Bjelovar Subdepression, Northern Croatia. Rudarsko-geološko-Naftni Zbornik. Min. Geol. Pet. Bull. 2016, 31, 75-86. [CrossRef]

33. Debashree, P.; Rajnish, S.; Rajeev Ranjan, K.; Joseph, Z.; Ajit, K.; Agarwal, P.; Surey, K.S.; Bandyopadhyay, A.; Talreja, R.; Nandi, A.; et al. Advanced Acoustic Measurements Aided Rock Mechanics Calculation for Successful Hydrofracturing Design and Wellbore Stability Analysis in Unconventional Reservoirs of Western Onshore, India; paper SPE-202802-MS. In Proceedings of the Abu Dhabi International Petroleum Exhibition \& Conference, Abu Dhabi, United Arab Emirates, 9 November 2020. [CrossRef]

34. Balanza, J.A.; Justiniano, L.C.; Poletzky, I. Implementation of Managed Pressure Casing Drilling and Managed Pressure Cementing Techniques in Unconventional Reservoirs; paper SPE/IADC-173080-MS. In Proceedings of the SPE/IADC Drilling Conference and Exhibition, London, UK, 17-19 March 2015. [CrossRef]

35. Jaripatke, O.; Samandarli, O.; McDonald, B.; Richmond, P. Completion Optimisation of an Unconventional Shale Play: Implementation of a Successful Completion Design Optimization Plan and the Results; paper SPE-170764-MS. In Proceedings of the SPE Annual Technical Conference and Exhibition, Amsterdam, The Netherlands, 27-29 October 2014. [CrossRef]

36. Dorman, J.; Lakatos, I.J.; Szentes, G.; Meidl, A. Mitigation of Formation Damage and Wellbore Instability in Unconventional Reservoirs Using Improved Particle Size Analysis and Design of Drilling Fluids; paper SPE-174260-MS. In Proceedings of the SPE European Formation Damage Conference and Exhibition, Budapest, Hungary, 3-5 June 2015. [CrossRef]

37. Li, S.; Osisanya, S.; Haroun, M. Development of New Smart Drilling Fluids Using Nano-Materials for Unconventional Reservoirs, paper SPE-183509-MS. In Proceedings of the Abu Dhabi International Petroleum Exhibition \& Conference, Abu Dhabi, United Arab Emirates, 7-10 November 2016. [CrossRef]

38. Senters, C.W.; Warren, M.N.; Squires, R.A.; Woodroof, R.A.; Leonard, R.S. Reducing Costs and Optimizing Drilling and Completion Efficiencies in Unconventional Plays Using Completion Diagnostics; paper SPE-174844-MS. In Proceedings of the SPE Annual Technical Conference and Exhibition, Houston, TX, USA, 28-30 September 2015. [CrossRef]

39. Murugesan, S.; Suresh, R.; Agrawal, D.; Darugar, Q.; Khabashesku, V. Unconventional Nanotechnology-Based Tracers for Drilling and Completion Applications; paper IPTC-19600-MS. In Proceedings of the International Petroleum Technology Conference, Dhahran, Saudi Arabia, 13-15 January 2020. [CrossRef]

40. Velić, J.; Malvić, T.; Cvetković, M.; Vrbanac, B. Reservoir geology, hydrocarbon reserves and production in the Croatian part of the Pannonian Basin System. Geol. Croat. 2012, 65, 91-101. [CrossRef] 